\title{
Growth and production of dwarf coconut in saline-sodic soil under doses of potassium sulfate
}

\author{
Tiago de A. Pereira ${ }^{1}$, Lauter S. Souto ${ }^{1}$, Francisco V. da S. Sá ${ }^{2}$, \\ João A. Dutra Filho', Tarso M. A. de Souza $^{3} \&$ Emanoela P. de Paiva ${ }^{3}$ \\ ${ }^{1}$ Universidade Federal de Campina Grande/Centro de Ciências e Tecnologia Agroalimentar/Unidade Acadêmica de Ciências Agrárias. Pombal, PB. \\ E-mail: tiago_agro2012@hotmail.com; lauter@ccta.ufcg.edu.br; filho-dutra@ig.com.br \\ ${ }_{2}^{2}$ Universidade Federal de Campina Grande/Centro de Tecnologia e Recursos Naturais/Unidade Acadêmica de Engenharia Agrícola. Campina Grande, \\ PB. E-mail: vanies_agronomia@hotmail.com (Corresponding author) \\ ${ }^{3}$ Universidade Federal Rural do Semi-Árido/Departamento de Ciências Vegetais. Mossoró, RN.E-mail: tarsomoreno.agro@gmail.com; emanuelappaiva@hotmail.com
}

\section{Key words:}

Cocos nucifera L. potassium fertilization soil sodicity

\begin{abstract}
A B S T R A C T
The objective was to study the influence of potassium sulfate doses applied to the soil on the growth and production of green dwarf coconut (Cocos nucifera L.) grown in saline-sodic soil. The experiment was conducted from January 2013 to January 2016, in a commercial plantation in the Sector 7 of the 'Várzeas de Sousa' Irrigation District, PB, Brazil, in salinesodic Ebanic Vertisol. The experiment used coconut plants belonging to green dwarf variety, arranged in a $7.0 \times 7.0 \mathrm{~m}$ rectangular shape, starting the third year in the production stabilization stage. The adopted experimental design was randomized blocks, evaluating five doses of potassium sulfate $\left(\mathrm{K}_{2} \mathrm{SO}_{4}\right)\left(0,0.52,1.04,2.08\right.$ and $4.16 \mathrm{~kg} \mathrm{plant}^{-1}$ year $\left.^{-1}\right)$, with four replicates of four plants each, totaling 20 experimental units. The $\mathrm{K}_{2} \mathrm{SO}_{4}$ doses positively influenced the growth and production of green dwarf coconut trees in saline-sodic soil. The highest growth in height and diameter of this coconut variety was obtained at the $\mathrm{K}_{2} \mathrm{SO}_{4}$ dose of $4.16 \mathrm{~kg} \mathrm{plant}^{-1}$ year $^{-1}$. The largest fruits and water volume in the first year of production were obtained with $\mathrm{K}_{2} \mathrm{SO}_{4}$ doses from 2.08 to $2.81 \mathrm{~kg}$ plant $^{-1}$ year $^{-1}$.
\end{abstract}

\section{Palavras-chave: \\ Cocos nucifera L. adubação potássica sodicidade do solo}

\section{Crescimento e produção do coqueiro anão em solo salino-sódico sob doses de sulfato de potássio}

\begin{abstract}
R E S U M O
Objetivou-se, com este trabalho, avaliar a influência de doses de sulfato de potássio aplicado via solo no crescimento e produção do coqueiro anão verde (Cocos nucifera L.) cultivado em solo salino-sódico. O experimento foi conduzido durante os meses de janeiro de 2013 a janeiro de 2016, em pomar comercial, no Setor 7 das Várzeas de Sousa, PB, em Vertissolo Ebânico. Utilizaram-se plantas de coqueiro pertencentes à variedade anã verde, espaçadas em formato retangular 7,0 x 7,0 m, iniciando o terceiro ano em fase de estabilização de produção. Adotou-se o delineamento experimental em blocos casualizados avaliando cinco doses de sulfato de potássio $\left(\mathrm{K}_{2} \mathrm{SO}_{4}\right)\left(0 ; 0,52 ; 1,04 ; 2,08\right.$ e $4,16 \mathrm{~kg} \mathrm{planta}^{-1}$ ano $\left.^{-1}\right)$, com quatro repetições, sendo quatro plantas úteis por repetição totalizando 20 unidades experimentais. As doses de $\mathrm{K}_{2} \mathrm{SO}_{4}$ influenciaram positivamente o crescimento e a produção do coqueiro anão verde em solo salino-sódico. $\mathrm{O}$ maior crescimento em altura e diâmetro da estirpe do coqueiro foi obtido sob a dose de $4,16 \mathrm{~kg}_{\text {planta }}{ }^{-1} \mathrm{ano}^{-1}$ de $\mathrm{K}_{2} \mathrm{SO}_{4}$. Os maiores frutos e volume de água no primeiro ano de produção foram obtidos com as quantidades aplicadas de 2,08 a 2,81 kg planta ${ }^{-1}$ ano $^{-1}$ de $\mathrm{K}_{2} \mathrm{SO}_{4}$.
\end{abstract}




\section{INTRODUCTION}

Coconut (C. nucifera L.) is a plant typical of tropical climate and has more than 300 ecotypes and two main varieties: giant (allogamous variety) and dwarf (autogamous variety), and the latter has the sub-varieties green, red and yellow (Farias Neto et al., 2009). Brazil is the third largest coconut producer, with about 280 thousand cultivated hectares and production of 2 billion fruits.

The Northeast is the main producing region, representing $85.6 \%$ of the total national production of coconut, but a large portion of the plantations is found in areas affected by salinity and/or sodicity (Ferreira Neto et al., 2002, 2007a; Marinho et al., 2006; Holanda et al., 2007; Lima et al., 2015). In these areas, salinity and sodicity effects are the main causes of environmental degradation, and soil sodicity is more harmful than salinity, leading to dispersion of clays, which results in physical and chemical impoverishment and loss of agricultural functions of the previously productive lands. In addition, it causes toxicity problems in the plants, affecting the absorption of nutrients and reducing their growth and production (Pequeno et al., 2014; Mesquita et al., 2015; Sá et al., 2015).

Potassium fertilization is of great importance for various fruit crops, because it interferes with the quantity and quality of the produced fruits (Silva et al., 2006, 2009). In an attempt to meet the nutritional requirements, the supply of nutrient in adequate portions is one of the greatest difficulties faced by the coconut producers (Ferreira Neto et al., 2007b, 2011, 2014). Regarding coconut yield, there are innumerous studies highlighting the potential of potassium fertilization in the increment of plant growth and production (Sobral \& Nogueira, 2008; Silva et al., 2009; Ferreira Neto et al., 2014; Ribeiro et al., 2016). Thus, this study aimed to evaluate the influence of potassium sulfate doses applied via soil on the growth and production of green dwarf coconut (C. nucifera L.) cultivated in saline-sodic soil.

\section{Material ANd Methods}

The experiment was carried out from January 2013 to January 2016, in a commercial plantation, in the Sector 7 of the 'Várzeas de Sousa' Irrigation District, PB, in saline-sodic typic Ebanic Vertisol (Santos et al., 2013), at the geographic coordinates $06^{\circ} 57^{\prime} 40^{\prime \prime} \mathrm{S}$ and $37^{\circ} 48^{\prime} 22^{\prime \prime} \mathrm{W}$. The lot has an area of 5 ha planted with 1100 coconut plants and is under influence of the BSh' hot semi-arid climate, according to Köppen's classification, with mean annual temperature around $27^{\circ} \mathrm{C}$ and mean rainfall of $800 \mathrm{~mm}$ year ${ }^{-1}$; however, it is worth highlighting the irregular temporal and spatial distribution of these rainfalls.

The green dwarf coconut has slow growth, reproduction through self-fertilization, greater precocity and produces a large number of fruits during the entire production period, in relation to the giant coconut. Fruit production stabilization occurs in the $6^{\text {th }}$ year of cultivation, period in which the commercial plantation reaches its productive potential when adequately managed.

Before applying the treatments, the soil of the studied area was analyzed to determine its physical-chemical characteristics. For that, sampling was performed in the $0-20 \mathrm{~cm}$ layer and then the composite sample from 20 subsamples was taken to the Laboratory of Irrigation and Salinity of the UFCG, after performing the soil analysis (Table 1).

The experiment was installed in randomized block design to evaluate five doses of potassium sulfate $\left(\mathrm{K}_{2} \mathrm{SO}_{4}\right)(0 ; 0.52$; $1.04,2.08$ and $4.16 \mathrm{~kg} \mathrm{plant}^{-1}$ year $\left.^{-1}\right)$, with four replicates and four plants per replicate, totaling 20 experimental units, at 7.0 × $7.0 \mathrm{~m}$ rectangular spacing. Plants were conducted for three years and the potassium doses were split in intervals of 90 days between applications, totaling 12 applications along the experiment.

The water used for irrigation came from the CoremasMãe D’Água dam and was applied in the experiment through Rondo pressure-compensating sprinklers, with green nozzle, hole diameter of $1.4 \mathrm{~mm}$, nominal flow rate of $53 \mathrm{~L} \mathrm{~h}^{-1}$, which operated at pressure of $150 \mathrm{kPa}$, promoting a radius of throw of $3.2 \mathrm{~m}$. One emitter was installed beside each plant, totaling 20 micro-sprinklers per lateral line, mounted along the four planting rows, placed $50 \mathrm{~cm}$ away, parallel to the stem. The pipe of the lateral lines is made of low-density polyethylene, with external diameter of $16 \mathrm{~mm}$ and internal diameter of $13 \mathrm{~mm}$. Irrigation was applied on a daily frequency, in the morning for 3 to $4 \mathrm{~h}$ a day, during the entire experimental period.

The irrigation volume applied in the coconut was estimated based on the reference evapotranspiration (ETo) calculated by the Penman-Monteith method (Allen et al., 1998). The crop coefficient $(\mathrm{Kc})$ adopted for the coconut along the entire period was equal to $1.0 \mathrm{~m}$, based on experiments conducted under the local climate conditions of this experiment. In Brazil, in general, a Kc of 0.8 for adult plants has been used to calculate the amount of water applied in the coconut crop (Nogueira et al., 1997), highlighting the peculiarity of each climatic environment for the adjustment of this factor.

Table 1. Initial physical-chemical analysis of the saline-sodic typic Ebanic Vertisol in the layer of 0-30 $\mathrm{cm}$

\begin{tabular}{|c|c|c|c|c|c|c|c|c|c|}
\hline \multicolumn{10}{|c|}{ Chemical characteristics } \\
\hline \multirow{2}{*}{ pHse } & \multirow{2}{*}{$\begin{array}{c}\mathrm{OM} \\
\text { dag } \mathrm{kg}^{-1}\end{array}$} & \multirow{2}{*}{$\begin{array}{c}P \\
\mathrm{mg} \mathrm{kg}^{-1}\end{array}$} & $\mathrm{~K}^{+}$ & $\mathrm{Na}^{+}$ & $\mathrm{Ca}^{+2}$ & $\mathrm{Mg}^{+2}$ & $\mathrm{Al}^{+3}+\mathrm{H}^{+}$ & \multirow{2}{*}{$\begin{array}{c}\text { ESP } \\
\%\end{array}$} & \multirow{2}{*}{$\begin{array}{l}\text { ECse } \\
\text { dS m-1 }\end{array}$} \\
\hline & & & \multicolumn{5}{|c|}{$\left(\mathrm{cmol}_{\mathrm{c}} \mathrm{kg}^{-1}\right)$} & & \\
\hline 7.07 & 1.36 & 22.60 & 0.15 & 8.26 & 6.42 & 8.69 & 0.00 & 35.12 & 10.60 \\
\hline \multicolumn{10}{|c|}{ Physical characteristics } \\
\hline \multicolumn{3}{|c|}{ Granulometry } & \multirow{3}{*}{$\begin{array}{l}\text { Textural } \\
\text { Class }\end{array}$} & Moi & $(\mathrm{kPa})$ & & \multirow{3}{*}{$\begin{array}{l}\text { Total porosity } \\
\qquad \mathbf{m}^{3} \mathrm{~m}^{-3}\end{array}$} & \multirow{2}{*}{ DA } & \multirow{2}{*}{ DP } \\
\hline Sand & Silt & Clay & & 33.42 & 1519.5 & AW & & & \\
\hline \multicolumn{3}{|c|}{$\mathrm{g} \mathrm{kg}^{-1}$} & & \multicolumn{3}{|c|}{ dag $\mathrm{kg}^{-1}$} & & \multicolumn{2}{|c|}{$\mathrm{kg} \mathrm{dm}^{-3}$} \\
\hline 330.9 & 382.6 & 286.5 & Clay loam & 14.94 & 6.13 & 8.81 & 49.67 & 1.11 & 2.72 \\
\hline
\end{tabular}

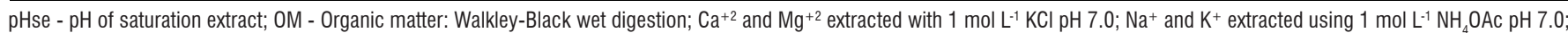
ECse - Electrical conductivity of saturation extract; AW - Available water; DA - Apparent density; DP - Particle density 
Weeds were controlled through mowing and manual removal around the plants every two months. Leaves in the senescence stage were removed from the plants.

Along the experiment, the following variables were evaluated: stem height (SH), measured from the soil level to the insertion of leaves in the stem, using a tape measure; stem diameter (SD), measured using a tape measure at $1.0 \mathrm{~m}$ from the soil level; number of fruits per plant (NFP), through manual count; fruit equatorial circumference (FEC), measured with a tape measure; fruit weight (FW), obtained by weighing the fruits on a high-precision digital scale; water volume per fruit (WVF), by selecting two fruits of each plant, totaling 8 fruits per replicate. After the fruits were opened, the water volume was measured in a $500-\mathrm{mL}$ graduated cylinder; total soluble solids (TSS, $\left.{ }^{\circ} \mathrm{Brix}\right)$ were determined using a benchtop digital refractometer. Since the production of the region is directed to coconut water consumption, the fruits were harvested green, approximately 7 months old, from the opening of the inflorescence.

The obtained data were subjected to analysis of variance by F test, with regression analysis (linear and polynomial), using the Software Sisvar (Ferreira, 2011).

\section{Results AND Discussion}

There was influence of the potassium sulfate doses on all growth and production variables studied, at 0.05 probability level $(\mathrm{p}<0.05)$ (Figures 1 and 2). For the growth in height and stem diameter, there was an increasing linear behavior due to the increase in $\mathrm{K}_{2} \mathrm{SO}_{4}$ doses, with unit increments of 5.91 and $2.01 \mathrm{~cm}$, respectively, for height (Figure $1 \mathrm{~A}$ ) and stem diameter (Figure 1B).

Stem height was $34.2 \%$ lower in the treatment without addition of $\mathrm{K}_{2} \mathrm{SO}_{4}$ in comparison to the highest height of the treatment with $4.16 \mathrm{~kg}$ plant ${ }^{-1}$ year ${ }^{-1}$ of $\mathrm{K}_{2} \mathrm{SO}_{4}$, with values of

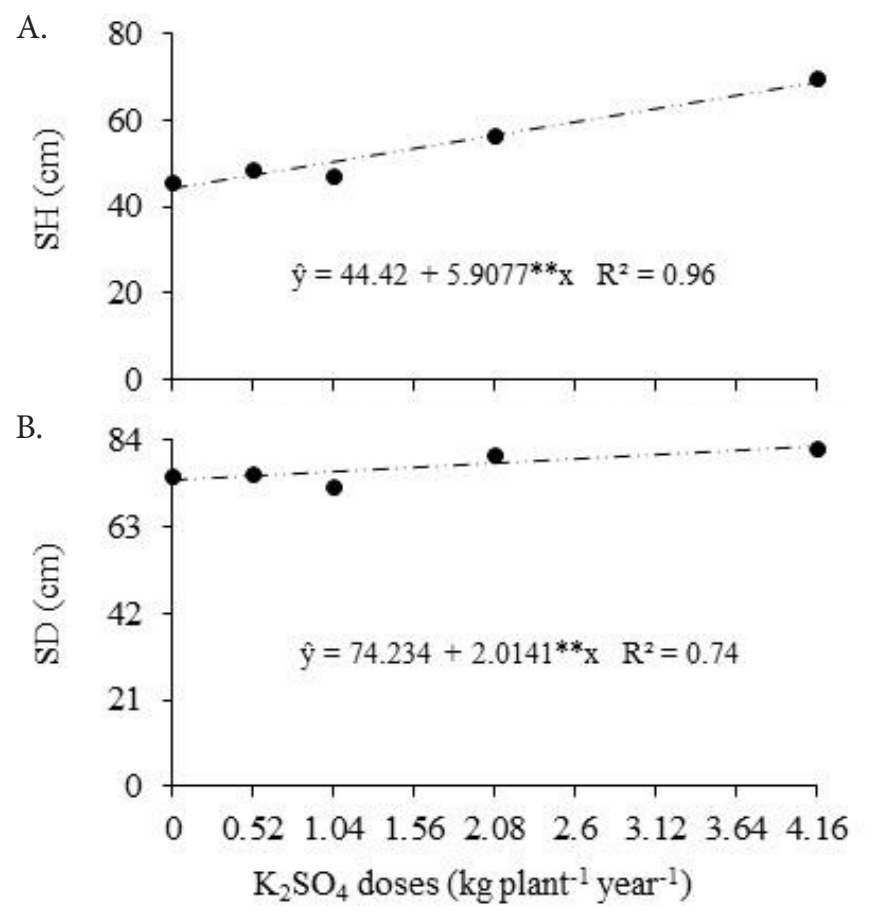

Figure 1. Stem height $(\mathrm{SH})(\mathrm{A})$ and stem diameter (SD) (B) in the third year of green dwarf coconut cultivated in saline-sodic soil under potassium sulfate doses
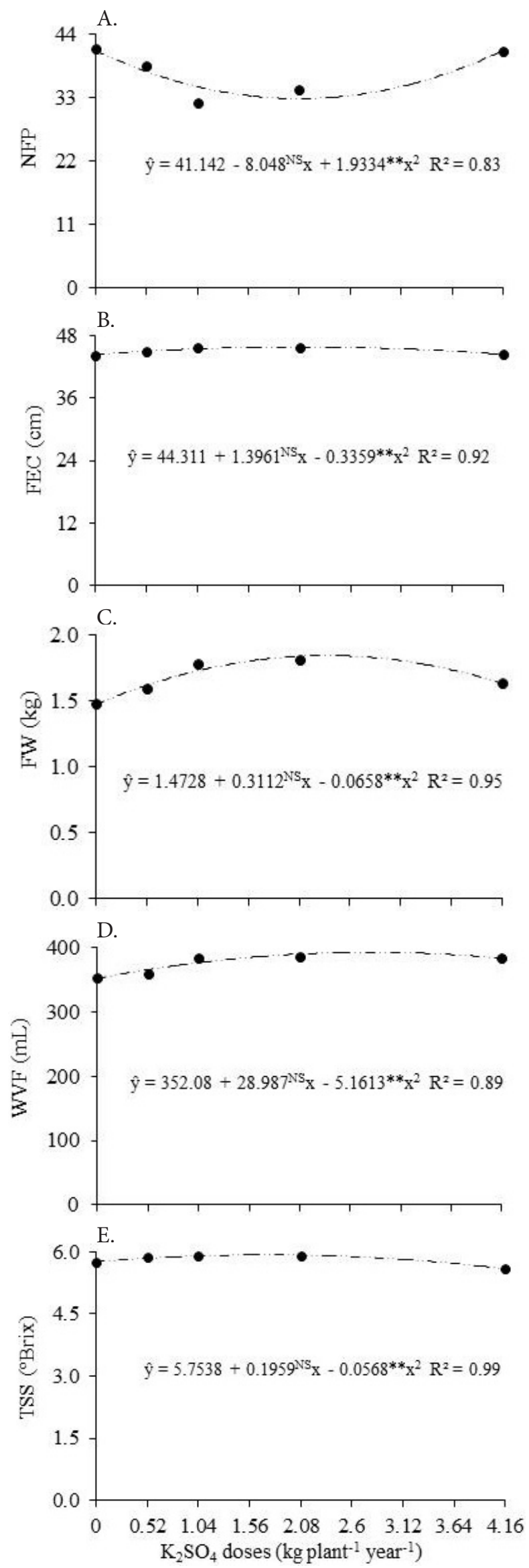

Figure 2. Number of fruits per pant (NFP) (A), fruit equatorial circumference (FEC) (B), fruit weight (FW) $(C)$, water volume per fruit (WVF) (D) and total soluble solids (TSS) (E) in the third year of green dwarf coconut cultivated in saline-sodic soil under potassium sulfate doses 
45.8 and $69.75 \mathrm{~cm}$, respectively (Figure $1 \mathrm{~A}$ ). Thus, the $\mathrm{K}_{2} \mathrm{SO}_{4}$ dose of $4.16 \mathrm{~kg}_{\text {plant }}{ }^{-1}$ year-1 was sufficient for both coconut plants to express the greatest growth. These results corroborate those found by Ferreira Neto et al. (2011), who observed similar response evaluating the effect of $\mathrm{K}$ fertilization on green dwarf coconut in the amounts of 0, 1.0, 2.0, 3.0, 4.0 and $5.0 \mathrm{~kg} \mathrm{plant}^{-1}$ year $^{-1}$, in Parnamirim, Rio Grande do Norte.

The $\mathrm{K}_{2} \mathrm{SO}_{4}$ dose of $4.16 \mathrm{~kg}_{\text {plant }}{ }^{-1}$ year ${ }^{-1}(84 \mathrm{~cm})$ showed the best result of stem diameter, with increment of $9.0 \%$ in relation to the control (without addition of $\left.\mathrm{K}_{2} \mathrm{SO}_{4}\right)(75 \mathrm{~cm}$ ) (Figure 1B). Similar results were obtained by Ferreira Neto et al. (2011), who evaluated the effect of increasing $\mathrm{K}$ doses on the coconut crop and observed greater stem diameters at higher potassium doses.

Regarding the number of fruits, there was a decrease in fruit production due to the increment in $\mathrm{K}_{2} \mathrm{SO}_{4}$ doses up to $2.08 \mathrm{~kg} \mathrm{plant}^{-1}$ year $^{-1}$, with subsequent increment up to the dose of $4.16 \mathrm{~kg} \mathrm{plant}^{-1}$ year $^{-1}$; however, plants cultivated without addition of $\mathrm{K}_{2} \mathrm{SO}_{4}$ obtained the highest number of fruits, 42.5 fruits plant $^{-1}$ (Figure 2A).

The greater fruit production in plants that did not receive potassium fertilization coincided with the lowest results obtained for size, weight and water volume of the fruit in the control treatment (Figures $2 \mathrm{~B}, \mathrm{C}$ and D), indicating that the potassium fertilization had benefits on dwarf coconut growth and yield in saline-sodic soil, since at the $\mathrm{K}_{2} \mathrm{SO}_{4}$ dose of 2.08 $\mathrm{kg}_{\text {plant }}{ }^{-1}$ year $^{-1}$ the coconut plants produced a lower number of fruits in relation to the control; however, the produced fruits showed higher values of weight and water volume, denoting the beneficial effects of $\mathrm{K}_{2} \mathrm{SO}_{4}$ fertilization (Figures $2 \mathrm{~A}, \mathrm{C}$ and D).

The adequate supply of potassium and sulfur for the coconut crop is important because of its requirement and there may be deficiency and decrease in coconut water quality when the availability of these nutrients is low. Teixeira et al. (2005) report the importance of the supply of $\mathrm{N}, \mathrm{P}$ and $\mathrm{K}$ in the dwarf coconut crop to increase the mean contents of $\mathrm{K}$ in the leaf tissue, and observed that for every $100 \mathrm{~kg}$ of $\mathrm{K}_{2} \mathrm{O}$ plant $^{-1}$ year $^{-1}$ there was an increment of $0.92 \mathrm{~g} \mathrm{~kg}^{-1}$ of $\mathrm{K}$ in the leaves.

For the variables fruit equatorial circumference, fruit weight, water volume per fruit and total soluble solids, there was a quadratic behavior due to the increase in $\mathrm{K}_{2} \mathrm{SO}_{4}$ dose, with maximum values of $45.76 \mathrm{~cm} ; 1.84 \mathrm{~kg}_{\text {fruit }}^{-1} ; 392.78 \mathrm{~mL}$ fruit $^{-1}$ and $5.92{ }^{\circ} \mathrm{Brix}$, at the doses of $2.08 ; 2.36 ; 2.81$ and 1.72 $\mathrm{kg}$ of $\mathrm{K}_{2} \mathrm{SO}_{4}$ plant $^{-1}$ year $^{-1}$, respectively (Figures $2 \mathrm{~B}, \mathrm{C}, \mathrm{D}$ and E). Although the production results obtained in the present study are lower than those found in the literature for green dwarf coconut plants under potassium fertilization (Sobral \& Nogueira, 2008; Silva et al., 2009; Ribeiro et al., 2011, 2016), this is due to the conditions of salinity and sodicity of the soil, besides the young conditions of the plants and their small size, since they are in the third year of cultivation. However, the effects of potassium fertilization on the increment in the number of fruits per plant are mainly observed from the $6^{\text {th }}$ year of cultivation of the green dwarf coconut (Ferreira Neto et al., 2007b).

The beneficial effects of $\mathrm{K}_{2} \mathrm{SO}_{4}$ fertilization observed in the present study can possibly be even more promising in adult green dwarf coconut plants grown in soils affected by salts and sodium, since potassium fertilization increases the availability of the nutrient in the soil, increasing the EC and thus reducing the effect of soil salinity and sodicity on the plant (Marinho et al., 2006; Ferreira Neto et al., 2007a, 2014). Consequently, the increase in potassium availability promotes satisfactory conditions for growth, development and production of the plants, especially the coconut crop, due to its high requirement for this nutrient (Sobral \& Nogueira, 2008; Silva et al., 2009; Ferreira Neto et al., 2014; Ribeiro et al., 2016). In addition, when applied in the form of $\mathrm{K}_{2} \mathrm{SO}_{4}$, potassium promotes supply of sulfur and, after potassium sulfate dissociation, part of the $\mathrm{SO}_{4}^{2-}$ binds to sodium ions, promoting their movement in subsurface in the soil, with the irrigation events. Therefore, it decreases sodicity in the effective root zone of the plant (Mesquita et al., 2015; Sá et al., 2015).

\section{Conclusions}

1. $\mathrm{K}_{2} \mathrm{SO}_{4}$ doses positively influenced the growth and production of green dwarf coconut.

2 . The greatest growth in coconut height and stem diameter was obtained at the $\mathrm{K}_{2} \mathrm{SO}_{4}$ dose of $4.16 \mathrm{~kg}_{\text {plant }}{ }^{-1}$ year $^{-1}$.

3. The largest fruits and water volume in the first year of production were obtained with $\mathrm{K}_{2} \mathrm{SO}_{4}$ doses from 2.08 to 2.81 kg plant $^{-1}$ year $^{-1}$.

\section{Literature Cited}

Allen, R. G.; Pereira, L. S.; Raes, D.; Smith, M. Crop evapotranspiration: Gigelines for computing crop water requirements. Rome: FAO, 1998. 300p. FAO Irrigation and Drainage Paper 56

Farias Neto, J. T.; Lins, P. M. P.; Resende, M. D. V. de; Muller, A. A. Seleção genética em progênies híbridas de coqueiro. Revista Brasileira de Fruticultura, v.31, p.190-196, 2009. https://doi. org/10.1590/S0100-29452009000100026

Ferreira, D. F. Sisvar: A computer statistical analysis system. Ciência e Agrotecnologia, v.35, p.1039-1042, 2011. https://doi.org/10.1590/ S1413-70542011000600001

Ferreira Neto, M.; Gheyi, H. R.; Fernandes, P. D.; Holanda, J. S. de; Blanco, F. F. Emissão foliar, relações iônicas e produção do coqueiro irrigado com água salina. Ciência Rural, v.37, p.16751681, 2007a. https://doi.org/10.1590/S0103-84782007000600026

Ferreira Neto, M.; Gheyi, H. R.; Holanda, J. S. de; Medeiros, J. F. de; Fernandes, P. D. Qualidade do fruto verde de coqueiro em função da irrigação com água salina. Revista Brasileira de Engenharia Agrícola e Ambiental, v.6, p.69-75. 2002. https://doi.org/10.1590/ S1415-43662002000100013

Ferreira Neto, M.; Holanda, J. S. de; Dias, N. da S.; Gheyi, H. R.; Folegatti, M. V. Crescimento e produção de coqueiro Anão verde fertigado com nitrogênio e potássio. Revista Brasileira de Engenharia Agrícola e Ambiental, v.15, p.657-664, 2011. https:// doi.org/10.1590/S1415-43662011000700002

Ferreira Neto, M.; Holanda, J. S. de; Folegatti, M. V.; Gheyi, H. R.; Pereira, W. E.; Cavalcante, F. C. Qualidade do fruto do coqueiro anão verde em função de nitrogênio e potássio na fertirrigação. Revista Brasileira Engenharia Agrícola Ambiental, v.11, p.453458, 2007b. https://doi.org/10.1590/S1415-43662007000500001 
Ferreira Neto, M.; Holanda, J. S. de; Gheyi, H. R.; Folegatti, M. V.; Dias, N. da S. Atributos químicos do solo e estado nutricional de coqueiro anão fertirrigado com nitrogênio e potássio. Revista Caatinga, v.27, p.30-40, 2014.

Holanda, J. S. de; Oliveira, M. T.; Espínola Sobrinho, E.; Dantas, T. B. Tecnologias para produção intensiva de coco anão. Natal: EMPARN, 2007. 40p. Boletim de Pesquisa

Lima, S. A. J.; Machado, A. V.; Cavalcanti, M. T.; Lisbôa, C. G. C. de. Análise sensorial da água de coco anão verde processada e comercializada no sertão paraibano e cearense. Revista Verde de Agroecologia e Desenvolvimento Sustentável, v.10, p.165-169, 2015. https://doi.org/10.18378/rvads.v10i1.3466

Marinho, F. J. L.; Gheyi, H. R.; Fernandes, P. D.; Holanda, J. S. de; Ferreira Neto, M. Cultivo de coco 'Anão Verde' irrigado com águas salinas. Pesquisa Agropecuária Brasileira, v.41, p.1277-1284, 2006. https://doi.org/10.1590/S0100-204X2006000800010

Mesquita, E. F. de; Sá, F. V. da S.; Bertino, A. M. P.; Cavalcante, L. F.; Paiva, E. P. de; Ferreira, N. M. Effect of soil conditioners on the chemical attributes of a saline-sodic soil and on the initial growth of the castor bean plant. Semina: Ciências Agrárias, v.36, p.25272538, 2015. https://doi.org/10.5433/1679-0359.2015v36n4p2527

Nogueira, L. C.; Nogueira, L. R. Q.; Miranda, F. R. Irrigação do Coqueiro. In: Ferreira, J. M. S.; Warwick, D. R. N.; Siqueira, L. A. A cultura do coqueiro no Brasil. 2.ed. Brasília: Embrapa-SPI; Aracaju: Embrapa-CPATC, 1997. 159-187p.

Pequeno, O. T. B. de L.; Silva, J. L. B. C. da; Brasileiro, I. M. do N. Fitoextração de sais através de estresse salino por atriplex nummularia em solo do semiárido paraibano. Revista Saúde e Ciência, v.3, p.37-52, 2014.

Ribeiro, G.; Monnerat, P. H.; Campanharo, M.; Rabelo, W. S. Qualidade do fruto de coqueiro anão verde em resposta à adubação potássica. Revista Caatinga, v.24, p.187-191, 2011.
Ribeiro, G.; Monnerat, P. H.; Campanharo, M.; Rabello, W. S. Adubação potássica aplicada na axila foliar e no solo em coqueiro anão verde. Revista Ceres, v.63, p.68-75, 2016. https://doi. org/10.1590/0034-737X201663010010

Sá, F. V. da S.; Mesquita, E. F.; Costa, J. D.; Bertino, A. M. P.; Araújo, J. L. Influência do gesso e biofertilizante nos atributos químicos de um solo salino-sódico e no crescimento inicial do girassol. Irriga, v.20, p.46-59, 2015. https://doi.org/10.15809/ irriga.2015v20n1p46

Santos, H. G. dos; Jacomine, P. K. T.; Anjos, L. H. C. dos; Oliveira, V. A. de; Lumbreras, J. F.; Coelho, M. R.; Almeida, J. A.; Cunha, T. J. F.; Oliveira, J. B. de. Sistema Brasileiro de classificação de solos. 4.ed. Brasília: Embrapa Produção de Informação, 2013. 353p.

Silva, R. A. da; Cavalcante, L. F.; Holanda, J. S. de; Paes, R. de A.; Madalena, J. A. da S. Crescimento e produção do coqueiro anão verde fertirrigado com nitrogênio e potássio. Revista Caatinga, v.22, p.161-167, 2009.

Silva, R. A. da; Cavalcante, L. F.; Holanda, J. S. de; Pereira, W. E.; Moura, M. F. de; Ferreira Neto, M. Qualidade de frutos do coqueiro-anão verde fertirrigado com nitrogênio e potássio. Revista Brasileira de Fruticultura, v.28, p.310-313, 2006. https:// doi.org/10.1590/s0100-29452006000200035

Sobral, L. F.; Nogueira, L. C. Influência de nitrogênio e potássio via fertirrigação, em atributos do solo, níveis críticos foliares e produção do coqueiro anão. Revista Brasileira de Ciência do Solo, v.32, p.1675-1682, 2008. https://doi.org/10.1590/S010006832008000400032

Teixeira, L. A. J.; Bataglia, O. C.; Buzetti, S.; Furlani Junior, E. Adubação com NPK em coqueiro anão-verde (Cocos nucifera L.) - Atributos químicos do solo e nutrição da planta. Revista Brasileira de Fruticultura, v.27, p.115-119, 2005. https://doi. org/10.1590/S0100-29452005000100031 